\title{
SYNTHESIS OF FLAX-G-COPOLYMERS UNDER PRESSURE FOR USE IN PHENOLIC COMPOSITES AS REINFORCEMENT
}

\author{
SUSHEEL KALIA ${ }^{1 *}$, AND B.S. KAITH ${ }^{2}$ \\ 1) Department of Chemistry, Singhania University, Pacheri Bari, Jhunjhunu - 333515 (Rajasthan) India \\ 2) Department of Chemistry, Dr. B.R. Ambedkar National Institute of Technology (Deemed University), Jalandhar - 144011 (Pb.) India
}

(Received: April 22, 2008 - Accepted: November1, 2008)

\begin{abstract}
In present paper, binary vinyl monomers mixtures such as methyl methacrylate (MMA) + vinyl acetate (VA), MMA + acrylamide (AAm) and MMA + styrene (Sty) have been graft copolymerized onto flax fiber. $21.32,38.80$ and $25.60 \%$ grafting have been found with MMA+VA, MMA+AAm and MMA+Sty binary monomer mixtures, respectively. Graft copolymers thus prepared were characterized with FTIR spectroscopy, scanning electron microscopy (SEM), TGA/DTA techniques and X-ray diffraction (XRD). Thermal stability of flax-g-poly(MMA+AAm) has been found to more than that of flax fiber and other graft copolymers. On grafting, percentage crystallinity decreases rapidly with reduction in its stiffness and hardness. Highest value of percentage crystallinity has been found in case of flax fiber in comparison to flax-g-copolymers. Synthesized graft copolymers were used as reinforcing material in phenolic composites. Composites thus prepared were subjected for the evaluation of some mechanical properties such as wear resistance, tensile strength and compressive strength.
\end{abstract}

Key words: Flax fiber, graft copolymers, IR, TGA/DTA, SEM, crystallinity and composites.

\section{INTRODUCTION}

Grafting of MMA onto cellulose and cellulosic derivatives is well investigated by chemical and radiation methods ${ }^{1}$. Graft copolymerization of MMA and its binary mixtures with different vinyl monomers onto cellulose and cellulosic derivatives using ceric ammonium nitrate as an initiator has been extensively studied ${ }^{2}$. Haque et $\mathrm{l}^{3}$ grafted MMA onto jute and reported the effect of temperature, initiator concentration and lignin content of jute on percentage grafting. However, graft yield has been found to decrease on beating ${ }^{4}$.

Abow-Zeid et $\mathrm{al}^{5}$ found that water soluble matters, pectin and lignin accelerate the graft copolymerization during the initial stages of the reaction and in the mean time impede termination during the later stages of the reaction. Grafting decreased the moisture regain and tensile strength of jute. However, it imparted rot-proofing properties to the substrate. Jute yarn was improved through in situ grafting under UV radiation technique using three different types of bulk monomers i.e. methyl methacrylate, butyl acrylate and styrene. The effects of variation in irradiation time, monomer concentration, and additives on the extent of grafting were studied ${ }^{6}$. Lin et $\mathrm{al}^{7}$ graft copolymerized bamboo cellulose with MMA and optimized different reaction parameters for getting maximum graft yield. Taga and Inagaki ${ }^{8}$ reported that $\mathrm{C}_{2}-\mathrm{C}_{3}$ hydroxylic groups of cellulose are the active sites for grafting of MMA.

Most of the cellulosic fibers possess both crystalline and amorphous regions. The X-ray pattern of crystalline polymers show both sharp features associated with regions of three-dimensional order and more diffused features characteristics of molecularly disordered substances like liquid. The occurrence of both types of features in the fibers indicates that ordered and disordered regions co-exist in crystalline polymers. Lower crystallinity means higher amorphous regions, which are more accessible to chemicals and water. Crystallinity is also related to strength and generally, higher the crystallinity, higher is the strength of the fibers if the polymer structures are same ${ }^{9,10}$.

In order to develop composites with better mechanical properties and environmental performance, it becomes necessary to increase the hydrophobicity of the natural fibers and to improve the interface between matrix and natural fibers. Grafting of natural fibers with vinyl monomers is one of the best methods to attain these improvements. Only few workers have reported the use of graft copolymers as reinforcing material in the preparation of composites. Kaith et $\mathrm{al}^{11-13}$ and Kalia et $\mathrm{al}^{14-16}$ have reported the reinforcement of plastics with graft copolymers of flax fibers and it has been found that composites reinforced with graft copolymers of flax fibers showed better mechanical properties in comparison to original flax reinforcement. Mechanical properties of composites reinforced with acrylate grafted henequen cellulosics fibers were studied. They found that best results could be obtained with poly(MMA) grafted cellulose fibers because of better fiber-matrix adhesion ${ }^{17}$. Since the use of flax-g-copolymers as reinforcing material in the preparation of composites is meagerly reported in literature, so in the present paper, we report the preparation of phenol-formaldehyde (PF) composites using flax-g-copolymers as reinforcing material.

\section{EXPERIMENTAL}

\section{Materials}

Flax (Linum usitatissimum) was obtained from the Department of Agronomy, CSK HP Agriculture University, Palampur (India). Physical properties and chemical composition of flax fiber have been listed by various authors ${ }^{18,19}$. Monomers were washed with $5 \%$ sodium hydroxide followed by water and were dried over anhydrous sodium sulphate. The dried monomers were distilled and the middle fraction was used. Libror AEG-220 (Shimadzu make) electronic balance was used for weighing purpose.

IR spectra, thermal analysis, SEM and XRD of the samples were recorded with Perkin Elmer RXI Spectrophotometer, Thermal Analyzer (LINSEIS L-81 11), Electron Microscopy Machine (LEO 435VP) and Bruker $\mathrm{D}_{8}$ Advance, respectively.

Composites were prepared in Compression Molding Machine (SANTEC, India). Mechanical studies such as wear-resistance of the composites were carried-out on Wear \& Friction Monitor (DUCOM, 20LE) and tensile strength, compressive strength of PF composites were carried on Universal Testing Machine (HOUNSFIELD, H25KS)

\section{Methods}

\section{Grafting of Binary Vinyl Monomer Mixtures onto Flax}

$0.5 \mathrm{gm}$ flax was immersed in $100 \mathrm{ml}$ of distilled water for 24 hours prior to their grafting. Known amount of binary monomer mixture and definite ratio of FAS- $\mathrm{H}_{2} \mathrm{O}_{2}$ as initiator were added to the reaction mixture. The reaction mixture was stirred and transferred to autoclave at a definite pressure $\left(8 \mathrm{Kg} / \mathrm{cm}^{2}\right)$ for a definite time interval (120 minutes). The graft copolymer was Soxhlet extracted with acetone for about 5-6 h so as to remove homopolymer. Further, the traces of homopolymer were separated from graft copolymer by stirring the graft copolymer in acetone for about $24 \mathrm{~h}$ using magnetic stirrer. After homopolymer extraction, grafted fiber was dried in oven at $50^{\circ} \mathrm{C}$ till a constant weight was obtained and percentage graft yield was calculated. The percentage grafting $\left(\mathrm{P}_{\mathrm{g}}\right)$ was calculated as follows:

$$
\mathrm{P}_{\mathrm{g}}=\frac{\mathrm{W}_{2}-\mathrm{W}_{1}}{\mathrm{~W}_{1}} \times 100
$$

Where $\mathrm{W}_{1}$ and $\mathrm{W}_{2}$ are the weights of original flax fibers and grafted flax fibers, respectively.

Infra Red Spectroscopy (IR)

IR spectra of the ungrafted and grafted flax fiber were taken with $\mathrm{KBr}$ pellets on PERKIN ELMER RXI Spectrophotometer.

Scanning Electron Microscopy (SEM)

Scanning electron microscopic studies of flax and its graft copolymers were carried-out on Electron Microscopy Machine (LEO 435 VP). Since cellu- 
lose has non conducting behaviour so it was gold plated to in order to prevent charge buildup on the sample. Scanning was synchronized with microscopic beam in order to maintain the small size over large distance relative to the specimen. The resulting images had a great depth of the field. A remarkable three-dimensional appearance with high resolution was obtained. The scans could easily verify the fact that cellulosic fibers lying apart in raw sample started forming bundles in the graft copolymers. DTA)

Thermo-gravimetric Analysis / Differential Thermal Analysis (TGA/

Thermogravimetric analysis and differential thermal analysis studies were carried-out in air at a heating rate of $10^{\circ} \mathrm{C} /$ minute on a thermal analyzer (LINSEIS, L-81 11).

X-Ray Diffraction (XRD) Studies

$\mathrm{X}$-ray diffraction studies were performed on X-ray diffractometer (Bruker AXS D8 Advance). X-ray diffraction studies were performed under ambient conditions on Bruker- $\mathrm{D}_{8}$ advance model using $\mathrm{Cu} \mathrm{K} \alpha\left(1.5418^{\circ} \mathrm{A}\right)$ radiation, Ni-filter and scintillation counter as detector at $40 \mathrm{KV}$ and $40 \mathrm{~mA}$ on rotation between $5^{\circ}$ to $50^{\circ}$ at $2 \theta$ scale at 1 second step size and increment of 0.01 degree with $0.5^{\circ}$ or $1.0 \mathrm{~mm}$ of divergent and anti-scattering slit. Percentage crystallinity and crystalline index were determined by using the wide angle $\mathrm{X}$-ray diffraction counts at $2 \theta$ angle close to $22^{\circ}$ and $18^{\circ}$. The counter reading at peak intensity at $22^{\circ}$ is said to represent the crystalline material and the peak intensity at $18^{\circ}$ corresponds to the amorphous material in cellulose material ${ }^{20}$. Percentage crystallinity (\% Crystalline) and crystalline index (C.I.) were calculated as follows:

$$
\begin{gathered}
\% \text { Crystalline }=\frac{I_{22}}{I_{22}+I_{18}} \times 100 \\
\text { C.I. }=\frac{I_{22}-I_{18}}{I_{22}}
\end{gathered}
$$

where $I_{22}$ and $I_{18}$ are the crystalline and amorphous intensities at $2 \theta$ scale close to 22 and $18^{\circ}$, respectively.

\section{Preparation of Composites}

A definite amount of phenol-formaldehyde resin (resole) with flax-g-copolymer fibers $(10: 0.5 \mathrm{w} / \mathrm{w})$ was thoroughly mixed. After thorough mixing of the flax-g-copolymer fibers and resin, the mixture was poured in molds. The surfaces of molds were coated on the inside with oleic acid to avoid adhesion of the mixture to the mold and to allow easy removal of the composites after their production. The whole assembly was then placed inside the hot press and cured at $90^{\circ} \mathrm{C}$ and a pressure of $10 \mathrm{Kg} / \mathrm{cm}^{2}$ for $5 \mathrm{~h}$. Composites thus prepared were subjected for the evaluation of different mechanical properties such as wear resistance, tensile strength and compressive strength. The numbers of specimens used for the determination of mechanical properties were three and tests were conducted at ambient laboratory conditions.

\section{Wear Test}

Wear resistance studies of composites were carried-out as per ASTM D 3702 on DUCOM make machine. Wear resistance was conducted against hardened steel disc having hardness of $60 \mathrm{HRC}$ and roughness Ra: $0.5 \mu \mathrm{m}$. Counter surface was polished using emery paper and cleaned with acetone before each sliding test. Samples $(3 \mathrm{~cm})$ for wear test were held against rotating counter surface at different speeds (100-600 RPM) and normal loads (1-4 Kg). Each test was conducted for 5 minutes of sliding. Loss of weight was used as a measure of wear

\section{Tensile Strength Test}

Testing of composites for tensile strength was done as per ASTM D 3039. The composite sample of $8 \mathrm{~cm}$ length was clamped between two jaws of the Universal Testing Machine. Each end of the jaws covered $2 \mathrm{~cm}$ of the sample. Rest of the $4 \mathrm{~cm}$ sample was used to study the tensile behaviour. Readings for force and extension were set at zero. The tests were conducted at constant strain rate of order of $5 \mathrm{~mm} / \mathrm{min}$. Tensile stress was applied till the failure of the sample and the load-extension curve was obtained.

\section{Compressive Strength Test}

Compressive strength studies of the composites were carried-out by using the procedure described in ASTM D 3410. Composite sample of $4 \mathrm{~cm}$ was held between two platforms and the strain rate was fixed at $2 \mathrm{~mm}$ per minute. The compression stress was applied till the failure of the sample. Total compression per unit force was noted.

\section{RESULTS AND DISCUSSION}

$\mathrm{C}_{2}, \mathrm{C}_{3}$ and $\mathrm{C}_{6}$ hydroxylic groups and $\mathrm{C}-\mathrm{H}$ groups are the active cites for grafting in cellulosic fibers. The grafting onto flax fibers in presence of FAS$\mathrm{H}_{2} \mathrm{O}_{2}$ takes place as per the mechanism proposed by Bhattacharya and Misra ${ }^{21}$. $\mathrm{OH}^{2}$ radicals get a lot of opportunities to strike the back-bone polymer and result in the abstraction of $\mathrm{H}$-atom, thereby, generating free radical sites on the back-bone, which further propagate the graft copolymerization through interaction with monomer species:

\section{${ }^{*} \mathrm{OH}+\mathrm{Flax}-\mathrm{H} \longrightarrow \mathrm{Flax}^{*}+\mathrm{H}_{2} \mathrm{O}$ \\ $\mathrm{Flax}^{*}+\mathrm{M} \longrightarrow \mathrm{Flax}-\mathrm{M}^{*} \stackrel{\mathrm{nM}}{\longrightarrow} \mathrm{Flax} \longrightarrow \mathrm{M} \underset{\mathrm{n}+1}{*}$ \\ Graft Co-polymer}

Where $\mathrm{M}$ denotes the monomer

Effect of Concentration of Binary Monomer Mixtures on Percent Grafting $\left(\mathbf{P}_{\mathrm{g}}\right)$

Grafting of binary vinyl monomer mixtures such as MMA+VA, MMA+AAm and MMA+Sty onto flax fiber using MMA $\left(1.96 \times 10^{-3} \mathrm{~mol} \mathrm{~L}^{-1}\right)$ as the same monomer for the three binary monomer mixtures, showed $21.32 \%$ $\left(\mathrm{VA}=2.16 \times 10^{-3} \mathrm{~mol} \mathrm{~L}^{-1}\right), 38.80 \%\left(\mathrm{AAm}=1.40 \times 10^{-3} \mathrm{~mol} \mathrm{~L}^{-1}\right)$ and $25.60 \%$ $\left(\right.$ Sty $\left.=1.73 \times 10^{-3} \mathrm{~mol} \mathrm{~L}^{-1}\right)$ grafting, respectively (Table 1$)$.

Table 1. Effect of concentrations of different binary monomer mixtures on $\mathrm{P}$

\begin{tabular}{|c|c|c|}
\hline Binary Monomers & $\begin{array}{c}\text { Concentrations }\left(\mathrm{x} \mathrm{10}^{-3}\right. \\
\left.\text { molL }^{-1}\right)\end{array}$ & $\mathrm{P}_{\mathrm{g}}$ \\
\hline MMA + VA & $1.96+2.16$ & 21.32 \\
\hline MMA + AAm & $1.96+1.40$ & 38.80 \\
\hline MMA + Sty & $1.96+1.73$ & 25.60 \\
\hline
\end{tabular}

The higher percentage grafting in case of these binary monomer mixtures can be explained by the fact that the addition of electron acceptor monomer (AAm) to MMA increase the reactivity of MMA towards grafting. The reactivity ratio values of monomer mixtures (MMA+AAm: $\left.r_{1}=2.53, r_{2}=0.82\right)$ ] indicates that $r_{2}$ value of AAm is very small, which indicates that these monomers react with MMA in preference to their monomeric units thereby producing more of growing copolymeric chains and hence higher percentage of grafting. Whereas, higher reactivity ratio of MMA ( $r_{1}$ ) indicates that MMA radicals react with its own monomer thereby producing more homopolymer ${ }^{22}$. In case of $\mathrm{MMA}+\mathrm{VA}$ and MMA+Sty binary mixtures, two monomers with electron accepting and electron donating ability enter into a charge transfer complex formation thereby reducing the activity of monomers towards grafting. Moreover, both MMA and Sty are insoluble in water and hence accessibility of growing radicals to the active sites is poor. In addition to above factors, styrene also undergoes resonance stabilization, thereby resulting in low free radical sites on the monomeric units and hence a decreased graft yield has been observed.

Characterization of Graft Copolymers

\section{FTIR Spectroscopy}

Flax fiber showed broad peaks at $3422.8 \mathrm{~cm}^{-1}$ due to bonded $-\mathrm{OH}$ and at 2918.8, 1653.5 and $1058.7 \mathrm{~cm}^{-1}$ arising from $-\mathrm{CH}_{2}, \mathrm{C}-\mathrm{C}$ and C-O stretching, respectively. Whereas, graft copolymers showed additional peaks at 1734.7 
$\mathrm{cm}^{-1}$ due to carbonyl group of VA, $3311.7 \mathrm{~cm}^{-1}$ due to N-H stretching of AAm and $699.7 \mathrm{~cm}^{-1}$ due to aromatic stretching of styrene, in comparison to original flax fiber. This suggests that VA, AAm and Sty have been graft copolymerized onto flax fiber through covalent linkages.

\section{Scanning Electron Microscopy (SEM)}

A clear cut distinction between scanning electron micrographs of original flax and its graft copolymers, flax-g-poly(MMA+VA), flax-gpoly(MMA+AAM) and flax-g-poly(MMA+Sty) has been observed (Figs. $1-4)$.

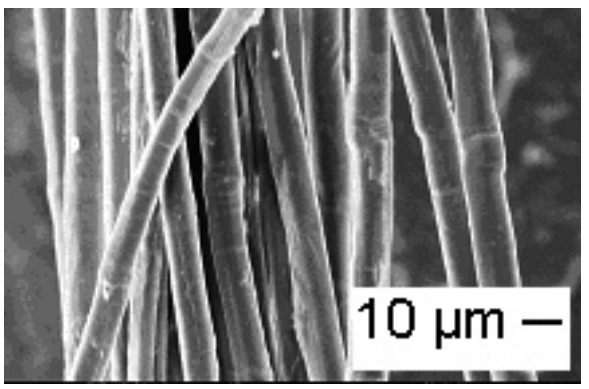

Figure 1 Fig. 1 SEM of flax

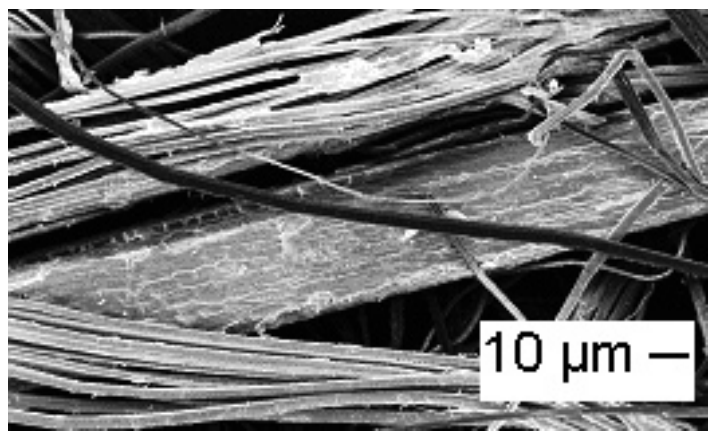

Figure 2 SEM of flax-g-poly(MMA+VA)

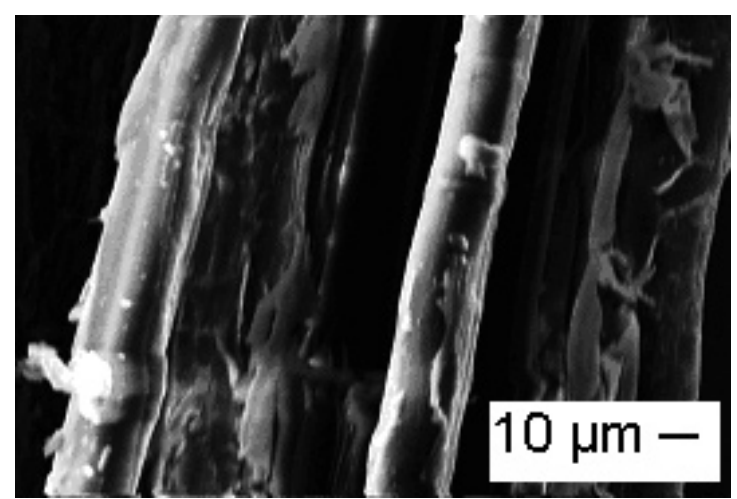

Figure 3 SEM of flax-g-poly(MMA/+AAm)

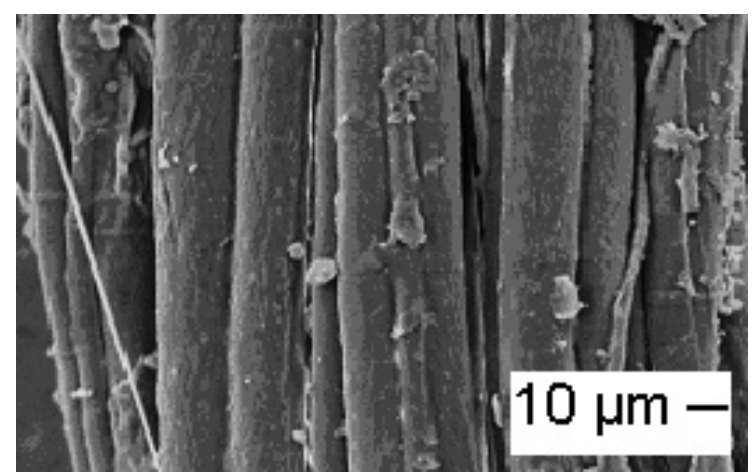

Figure 4 SEM of flax-g-poly(MMA+Sty)

Thermal Behaviour of Graft Copolymers

Thermal analysis of original flax fiber and graft copolymers were carriedout as a function of weight loss versus temperature. The results of thermogravimetric analysis (TGA) have been depicted in Table 2. In case of flax fiber, three stage decomposition has been observed with maximum weight loss occurring between $279.9-341.8^{\circ} \mathrm{C}(37.0 \%), 341.8-429.3^{\circ} \mathrm{C}(12.57 \%)$ and 429.3 $489.1^{\circ} \mathrm{C}(22.57 \%)$. Initial and final decomposition temperatures of original flax fiber are $279.9^{\circ} \mathrm{C}$ and $489.1^{\circ} \mathrm{C}$, respectively. In case of graft copolymers; flaxg-poly(MMA+VA), flax-g-poly(MMA+AAm) and flax-g-poly(MMA+Sty), the initial decomposition temperatures (IDTs) are $313.2,286.9$ and $316.7^{\circ} \mathrm{C}$, respectively and the final decomposition temperatures (FDTs) are 457.7, 499.9 and 454.4, respectively. It has been observed from above results that flax-gpoly(MMA+AAm) showed higher final decomposition temperature. Therefore, thermal stability of flax-g-poly(MMA+AAm) has been found to more than that of flax fiber and other graft copolymers.

Differential thermal analysis (DTA) of flax fiber showed an exothermic peaks at $325.3^{\circ} \mathrm{C}(13.8 \mu \mathrm{V})$ and $455.3^{\circ} \mathrm{C}(38.9 \mu \mathrm{V})$. These peaks show the disturbance in the $\mathrm{H}$-bonded amorphous region and complete break down of $\mathrm{C}-\mathrm{C}$ and $\mathrm{C}-\mathrm{O}$ bonds of the crystalline region. However, in case of graft, a continuous exothermic rise in temperatures has been observed. In case of flax-gpoly(MMA+AAm), sharp exothermic peaks have been observed at $369.6^{\circ} \mathrm{C}$ $(28.6 \mu \mathrm{V})($ Table 2$)$. With increase in percentage of grafting the crystal lattice of the flax gets disturbed, this results in the lower final decomposition temperature of the graft copolymers. Thus it has been observed that there exists a direct correlation between percentage of grafting and crystallinity.

Table 2. TGA/DTA of flax and its graft copolymers.

\begin{tabular}{|c|c|c|c|c|}
\hline \multirow{2}{*}{ Sr. No. } & Sample & \multicolumn{2}{|c|}{$\begin{array}{c}\text { Thermo- } \\
\text { gravimetric } \\
\text { analysis }\end{array}$} & $\begin{array}{c}\text { Differential } \\
\text { thermal analysis }\end{array}$ \\
\cline { 3 - 5 } & & $\begin{array}{c}\text { IDT } \\
\left({ }^{\circ} \mathrm{C}\right)\end{array}$ & $\begin{array}{c}\text { FDT } \\
\left({ }^{\circ} \mathrm{C}\right)\end{array}$ & $\begin{array}{c}\text { Exothermic } \\
\text { peaks at } \\
\text { temperature }(\mu \mathrm{V})\end{array}$ \\
\hline 1. & Flax fiber & 279.9 & 489.1 & $\begin{array}{l}325.3^{\circ} \mathrm{C}(13.8) \\
455.3^{\circ} \mathrm{C}(38.9)\end{array}$ \\
\hline 2. & Flax-g-poly(MMA+VA) & 313.2 & 457.7 & $354.1^{\circ} \mathrm{C}(29.3)$ \\
\hline 3. & $\begin{array}{c}\text { Flax-g- } \\
\text { poly(MMA+Am) }\end{array}$ & 286.9 & 499.9 & $369.6^{\circ} \mathrm{C}(28.6)$ \\
\hline 4. & Flax-g-poly(MMA+Sty) & 316.7 & 454.4 & $394.7^{\circ} \mathrm{C} \mathrm{(23.6)}$ \\
\hline
\end{tabular}

X-Ray Diffraction (XRD) Studies

It is evident from Table 3 that flax fiber, flax-g-poly(MMA+VA), flaxg-poly(MMA+AAm) and flax-g-poly(MMA+Sty) showed 76.96, 66.28, 66.47 and 66.48 percentage crystallinity, respectively. Crystallinity index of flax fiber, flax-g-poly(MMA+VA), flax-g-poly(MMA+AAm) and flax-gpoly(MMA+Sty) has been observed to be $0.7005,0.4911,0.4955$ and 0.4957 , respectively.

The X-ray spectrum of flax is more convex than that of graft copolymers (Fig. 5). In case of flax fiber, the incorporation of monomer chains to the back- 
bone of the flax had impaired the crystallinity of flax. Therefore, percentage crystallinity decreases rapidly on grafting.

A lower crystallinity index in case of flax-g-copolymers means poor order of cellulose crystals in the fiber. This is due to misorientation of the cellulose crystals to the fiber axis during grafting as indicated by the lower crystallinity index. This clearly indicates that the cellulose crystals are better oriented in flax fiber followed by flax-g-copolymers (Table 3) [14].

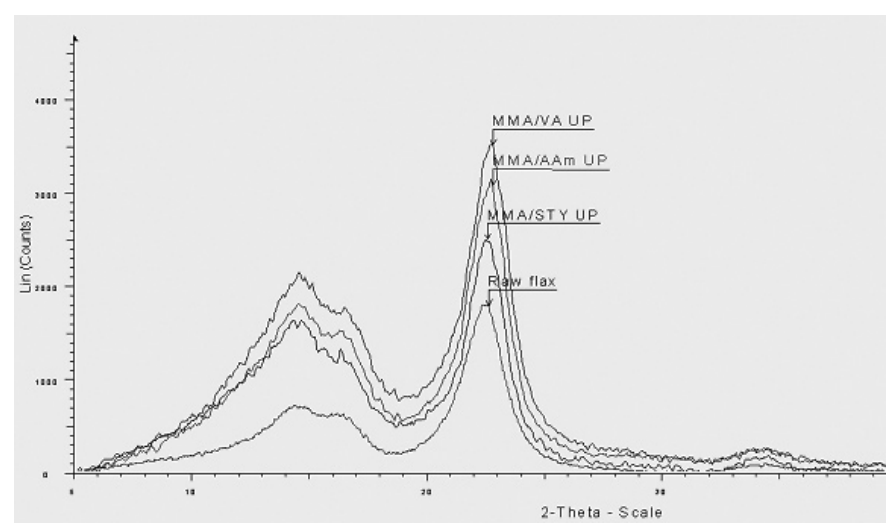

Figure $5 \mathrm{XRD}$ of flax and its graft copolymers

Table 3. Percentage crystallinity (\% Crystalline) and crystalline index (C.I.) of flax and flax-g-copolymers.

\begin{tabular}{|c|c|c|c|c|c|c|}
\hline \multirow{2}{*}{$\begin{array}{c}\text { Sr. } \\
\text { No. }\end{array}$} & Sample & $\mathrm{P}_{\mathrm{g}}$ & \multicolumn{2}{|c|}{ at $2 \theta$ scale } & \multirow{2}{*}{$\begin{array}{c}\text { \%Crys- } \\
\text { talline }\end{array}$} & C.I. \\
\hline 1. & Flax fiber & - & 1780 & 533 & 76.96 & 0.7005 \\
\hline 2. & $\begin{array}{c}\text { Flax-g- } \\
\text { poly(MMA+VA) }\end{array}$ & 21.32 & 3329 & 1694 & 66.28 & 0.4911 \\
\hline 3. & $\begin{array}{c}\text { Flax-g- } \\
\text { poly(MMA+AAm) }\end{array}$ & 38.80 & 2997 & 1512 & 66.47 & 0.4955 \\
\hline 4. & $\begin{array}{c}\text { Flax-g- } \\
\text { poly(MMA+Sty) }\end{array}$ & 25.60 & 2699 & 1361 & 66.48 & 0.4957 \\
\hline
\end{tabular}

Mechanical Properties of Flax-g-copolymers Reinforced Phenolic Composites

\section{Wear Resistance}

In case of reinforcement with graft copolymers prepared under pressure (UP), wear rate has been found to follow the same pattern (Table 4) as by the graft copolymers prepared in air $^{23}$ and under the influence of microwave radiations ${ }^{24}$. As is evident from Table 4 that phenol-formaldehyde matrix showed $18,34,56$ and $77 \mathrm{gm} / \mathrm{m} \times 10^{-4}$ wear rate and flax fiber reinforced PF composites showed $10,14,17$ and $21 \mathrm{gm} / \mathrm{m} \times 10^{-4}$ wear rate at $1,2,3$ and $4 \mathrm{Kg}$ loads, respectively. Flax-g-poly(MMA+VA); flax-g-poly(MMA+AAm) and flax-g-

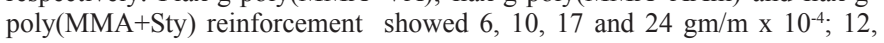
23,35 and $45 \mathrm{gm} / \mathrm{m} \mathrm{x} 10^{-4}$ and $9,13,19$ and $27 \mathrm{gm} / \mathrm{m} \times 10^{-4}$ wear rate at 1,2 , 3 and $4 \mathrm{Kg}$ loads, respectively. Maximum wear has been found in case of PF matrix and flax-g-poly (MMA+AAm) reinforcement. This is due to disturbance in crystalline structure of the fiber during grafting with MMA+AAm and fiber becomes prone to wear loss and the PF composites reinforced with such grafted fibers have least wear resistance. In case of reinforcement with flax-gpoly(MMA+VA) and flax-g-poly(MMA+Sty), wear resistance was improved at lower loads and it was nearer to that of flax reinforcement at higher loads. This is due to less percentage grafting with MMA+VA and MMA+Sty binary mixtures and hence least disturbance in crystal lattice ${ }^{11-17,23,24}$.
Table 4. Mechanical properties of flax fiber and flax-g-copolymers reinforced PF Composites.

\begin{tabular}{|c|c|c|c|c|c|c|}
\hline \multirow{2}{*}{ Sample } & \multirow{2}{*}{$\begin{array}{l}\text { Tensile } \\
\text { Strength } \\
\text { (N) }\end{array}$} & \multirow{2}{*}{$\begin{array}{l}\text { Compressive } \\
\text { Strength } \\
\text { (N) }\end{array}$} & \multicolumn{4}{|c|}{$\begin{array}{l}\text { Wear Rate }(\mathrm{gm} / \mathrm{m}) \times \\
10^{-4}\end{array}$} \\
\hline & & & $\begin{array}{c}1 \\
\mathrm{Kg}\end{array}$ & $\begin{array}{c}2 \\
\mathrm{Kg}\end{array}$ & $\begin{array}{c}3 \\
\mathrm{Kg}\end{array}$ & $\begin{array}{c}4 \\
\mathrm{Kg}\end{array}$ \\
\hline PF Matrix & 75 & 200 & 18 & 34 & 56 & 77 \\
\hline $\begin{array}{l}\text { Original flax } \\
\text { Reinforced PF } \\
\text { Composites }\end{array}$ & 150 & 400 & 10 & 14 & 17 & 21 \\
\hline $\begin{array}{c}\text { Flax-g- } \\
\text { poly(MMA+VA) } \\
\text { Reinforced PF } \\
\text { Composites }\end{array}$ & 75 & 1000 & 06 & 10 & 17 & 24 \\
\hline $\begin{array}{c}\text { Flax-g- } \\
\text { poly(MMA+AAm) } \\
\text { Reinforced PF } \\
\text { Composites }\end{array}$ & 50 & 700 & 12 & 23 & 35 & 45 \\
\hline $\begin{array}{c}\text { Flax-g- } \\
\text { poly(MMA+Sty) } \\
\text { Reinforced PF } \\
\text { Composites }\end{array}$ & 35 & 400 & 09 & 13 & 19 & 27 \\
\hline
\end{tabular}

Tensile Strength and Compressive Strength

Tensile strength of phenol-formaldehyde matrix and composites reinforced with flax fiber has been found to be 75 and 150 Newton force, respectively. Tensile strength of composites reinforced with flax-g-poly(MMA+VA), flaxg-poly(MMA+AAm) and flax-g-poly(MMA+Sty) has been found to be 75, 50 and 35 Newton force, respectively. It has been resulted that composites reinforced with graft copolymers prepared under pressure could not bear load beyond $50 \mathrm{~N}$ except reinforcement with flax-g-poly(MMA+VA) which was broken at $75 \mathrm{~N}$ with extension of $2.44 \mathrm{~mm}$ (Table 4).

Compressive strength of phenol-formaldehyde matrix and composites reinforced with flax fiber has been found to be 200 and 300 Newton force, respectively. In case of composites reinforced with flax-g-poly(MMA+VA), flax-g-poly(MMA+AAm) and flax-g-poly(MMA+Sty), compressive strength has been found to be 1000, 700 and 400 Newton force, respectively. It has been observed that pure phenol-formaldehyde blocks have been observed with least compressive strength and could not withstand beyond $200 \mathrm{~N}$ with compression of $0.62 \mathrm{~mm}$. It is quite evident from Table 4 that composites reinforced with graft copolymers prepared under pressure exhibited better compressive strength as and could bear load upto $1000 \mathrm{~N}$. Composites reinforced with flaxg-poly(MMA+VA) showed less compression $(1.38 \mathrm{~mm})$ and could bear load upto $1000 \mathrm{~N}$ whereas the composites reinforced with flax-g-poly(MMA+AAm) and flax-g-poly(MMA+Sty) could bear load upto $700 \mathrm{~N}$ and $400 \mathrm{~N}$ with compression of 2.42 and $0.77 \mathrm{~mm}$, respectively ${ }^{11-17,23,24}$.

\section{CONCLUSIONS}

Grafting with vinyl monomers is one of the best techniques for modifying the properties of natural polymers. Flax-g-poly(MMA+AAm) has been found to show good thermal stability in comparison to flax and other graft copolymers. Percentage crystallinity of flax decreases on grafting with binary vinyl monomers. Cellulose crystals are better oriented in flax fiber in comparison to graft copolymers. Composites reinforced with graft copolymers showed enhanced wear resistance and compressive strength mechanical properties.

\section{REFERENCES}

1.- O. Y. Mansour and A. Nagaty, J. Polym. Sci. Polym. Chem. Ed. 13, 2785, (1975).

2.- V. N. Sharma and E. H. Daruwalla, J. Appl. Polym. Sci. 21, 331, (1977).

3.- M. M. Haque, Md. Habiduddowla, A. J. Mahmood and A. J. Mian, J. Polym. Sci. Polym. Chem. Ed. 18, 144, (1980). 
4.- H. Kurosu and K. Horike, Chem. Abstr. 85, 22952u, (1976).

5.- N. Y. Abou-Zeid, A. Higazy and A. Hebeish, Angew Makromol. Chem. 121, 69, (1984).

6.- M. A. Khan, M. M. Rahman and K. S. Akhunzada, Polymer-Plastics Technology and Engineering 41, 677, (2002).

7.- K. C. Lin, Y. S. Lin and C. T. Hu, Proc. Natn. Sci. Coun. Republic China 5, 26, (1981).

8.- T. Taga and H. Inagaki, Chem. Abstr. 96, 3711Du, (1982).

9.- S. Ishikawa, J. Polym. Sci. Pol. Lett. 3, 959, (1965).

10.- M. Tsukada, J. Appl. Polym. Sci. 35, 965, (1988).

11.- B. S. Kaith, A. S. Singha, D. K. Dwivedi, S. Kumar, D. Kumar, and A. Dhemeniya, Int. J. Plast. Tech. 7, 119, (2003).

12.- D. K. Dwivedi, A. S. Singha, S. Kumar, and B. S. Kaith, Int. J. Plast. Tech. 8, 299, (2004).

13.- A. S. Singha, Susheel Kumar, and B. S. Kaith, Int. J. Plast. Tech. 9, 427, (2005).

14.- B. S. Kaith and S. Kalia, Fibers and Polymers 9, 416, (2008).
15.- B. S. Kaith, A. S. Singha, and Susheel Kalia, Int. J. Plast. Tech. 10, 572, (2006).

16.- B. S. Kaith, A. S. Singha, and Susheel Kalia, Autex Res. J. 7, 119, (2007).

17.- G. Canche-Escamilla, J. I. Cauich-Cupul, E. Mendiza'bal, J. E. Puig, H. Va'zquez-Torres, and P. J. Herrera-Franco, Composites: Part A 30, 349, (1999).

18.- M. J. John and R. D. Anandjiwala, Polym. Compos. 29, 187, (2008).

19.- J. George, M. S. Sreekala and S. Thomas, Polym. Eng. Sci. 41, 1471, (2001).

20.- B. S. Kaith and Susheel Kalia, e-Polymers no.002, (2008).

21.- A. Bhattacharya and B. N. Misra, Prog. Polym. Sci. 29, 767, (2004).

22.- J. Brandrup, E. H. Immergut, Editors, Polymer Handbook, Second Edition, Wiley Interscience, NY, pp. 105-386 (1975).

23.- B. S. Kaith and Susheel Kalia, Polym. J. 39, 1319, (2007).

24.- B. S. Kaith and Susheel Kalia, Polym. Compos. 29, 791, (2008). 